\title{
Realities of the Entrepreneurial Development Process in the Department of Galati, Romania
}

\author{
Daniela Ancuta SARPE ${ }^{\star}$, Mihaela NECULITA ${ }^{\star}$
}

\begin{tabular}{l}
\hline \multicolumn{1}{c}{ A R T I C L E I N F O } \\
\hline Article history: \\
Accepted March 2018 \\
Available online April 2019 \\
\hline JEL Classification \\
R58, L26 \\
Keywords: \\
Regional development, Smart \\
specialization, Innovative \\
entrepreneurship
\end{tabular}

1. Economic situation of Galati - some general data

The Department of Galati, located in the South-East of Romania, at the confluence of the Danube with the Siret and Prut rivers, has a population of about 600,000 , that is $2.8 \%$ of the population of Romania, while the capital of the department, Galati, the fifth largest city in the country, has about 300,000 inhabitants. Galati is an important industrial center, particularly in the steel, shipbuilding, textile and agro-food sectors. The metallurgical industry produces more than half of the country's steel production, giving importance to the port activity, which is closely linked to the steel industry. The mechanical sector is the most developed, with companies focused on the metal construction and metal products industry, the manufacture of ships, machinery and equipment. One of the most important strengths of Galati today remains the shipbuilding industry.

According to official statistics, the South-East region of Romania, where the Department of Galati is located, ranks fourth when it comes to the GDP per capita, in the hierarchy of Romanian development regions (7500 Euros/inhabitant in 2017). By analyzing the data in Table 1, one can notice that the evolution of the gross domestic product per capita in the South-East region between 2011 and 2016 showed an upward trend, coinciding with what was observed in Romania and in Europe. This can be explained by the phenomenon of economic recovery that followed the financial crisis. Moreover, by comparatively analyzing the developing regions, there were, however, significant disparities: in 2016, the South-East region had a 2.7 times lower GDP/capita than the Bucharest-Ilfov region, the most developed of the eight regions of the country.

Table 1. Regions of Romania - GDP/capita (Euros)

\begin{tabular}{|l|c|c|c|c|c|c|}
\hline Region & $\mathbf{2 0 1 1}$ & $\mathbf{2 0 1 2}$ & $\mathbf{2 0 1 3}$ & $\mathbf{2 0 1 4}$ & $\mathbf{2 0 1 5}$ & $\mathbf{2 0 1 6}$ \\
\hline North-West & 5,700 & 5,800 & 6,300 & 6,700 & 7,100 & 7,470 \\
\hline Center & 6,100 & 6,400 & 6,800 & 7,000 & 7,400 & 7,770 \\
\hline North-East & 3,900 & 4,200 & 4,500 & 4,600 & 4,900 & 5,145 \\
\hline South-East & 5,300 & 5,700 & 6,500 & 6,800 & 7,200 & 7,500 \\
\hline
\end{tabular}

\footnotetext{
${ }^{\star},{ }^{\star \star}$ Dunarea de Jos University of Galati, Romania. E-mail address: daniela.ancuta.sarpe@gmail.com (Corresponding author)
}

(C) 2019 EAI. All rights reserved. 


\begin{tabular}{|l|c|c|c|c|c|c|}
\hline Region & $\mathbf{2 0 1 1}$ & $\mathbf{2 0 1 2}$ & $\mathbf{2 0 1 3}$ & $\mathbf{2 0 1 4}$ & $\mathbf{2 0 1 5}$ & $\mathbf{2 0 1 6}$ \\
\hline South-Muntenia & 5,400 & 5,100 & 5,700 & 6,400 & 6,700 & 6,974 \\
\hline Bucharest-Ilfov & 17,100 & 15,600 & 16,900 & 17,600 & 19,300 & 20,340 \\
\hline South-West Oltenia & 5,000 & 5,000 & 5,300 & 5,400 & 5,700 & 5,870 \\
\hline West & 7,300 & 7,100 & 7,500 & 7,600 & 8,100 & 8,520 \\
\hline
\end{tabular}

Source: Eurostat 2018

At the departmental level, the highest GDP is recorded in the department of Constanta, followed distantly by the departments of Galati and Braila. The Department of Galati is the second with a GDP of $€$ 3,193 million in 2016 (see Table 2). The six departments of the South-East Region experienced a positive evolution during the period analyzed.

Table 2. Departments of the South-East Region of Romania - GDP (million euros)

\begin{tabular}{|l|c|c|c|c|c|c|}
\hline Department & $\mathbf{2 0 1 1}$ & $\mathbf{2 0 1 2}$ & $\mathbf{2 0 1 3}$ & $\mathbf{2 0 1 4}$ & $\mathbf{2 0 1 5}$ & $\mathbf{2 0 1 6}$ \\
\hline Braila & 1,661 & 1,579 & 1,684 & 1,657 & 1,708 & 1,764 \\
\hline Buzau & 1,874 & 1,986 & 2,175 & 2,124 & 2,202 & 2,286 \\
\hline Constanta & 5,224 & 6,066 & 6,993 & 7,635 & 7,855 & 8,365 \\
\hline Galati & 2,714 & 2,572 & 2,770 & 2,849 & 3,061 & 3,193 \\
\hline Tulcea & 1,225 & 1,113 & 1,196 & 1,160 & 1,231 & 1,294 \\
\hline Vrancea & 1,348 & 1,419 & 1,506 & 1,520 & 1,611 & 1,706 \\
\hline
\end{tabular}

Source: National Institute of Statistics 2017

\section{Presence and realities of SMEs in the Galati area}

The labour market in the department of Galati has also experienced strong momentum in recent years. The occupancy rate has changed from $44.1 \%$ to $54.7 \%$ - more than $24 \%$ growth for the period 2011 2015 (see Table 3), but remains low, compared to other departments in the South-East region (see Table 4) and the unemployment rate is still high in the Galati area - around 9\% since 2012.

Table 3. South-East Region: Occupancy rate by department (\%)

\begin{tabular}{|l|c|c|c|c|c|}
\hline Department & $\mathbf{2 0 1 1}$ & $\mathbf{2 0 1 2}$ & $\mathbf{2 0 1 3}$ & $\mathbf{2 0 1 4}$ & $\mathbf{2 0 1 5}$ \\
\hline Braila & 52.7 & 53.3 & 53.1 & 63 & 63.2 \\
\hline Buzau & 57.9 & 59.1 & 59.1 & 65.5 & 64.4 \\
\hline Constanta & 57.8 & 59.7 & 60.1 & 65 & 65.3 \\
\hline Galati & 44.1 & 45.1 & 45.2 & 54.7 & 54.7 \\
\hline Tulcea & 48.3 & 51.4 & 51 & 63.7 & 63.7 \\
\hline Vrancea & 55.8 & 58 & 56.7 & 68.9 & 68.1 \\
\hline $\begin{array}{l}\text { South-East } \\
\text { Region }\end{array}$ & 53 & 54.6 & 54.5 & 68.8 & 62.8 \\
\hline
\end{tabular}

Table 4. South-East Region: Unemployment rate by department (\%)

\begin{tabular}{|l|c|c|c|c|c|}
\hline Department & $\mathbf{2 0 1 1}$ & $\mathbf{2 0 1 2}$ & $\mathbf{2 0 1 3}$ & $\mathbf{2 0 1 4}$ & $\mathbf{2 0 1 5}$ \\
\hline Braila & 5.8 & 6.5 & 7 & 7.4 & 7.2 \\
\hline Buzau & 8 & 7.9 & 8.6 & 9.7 & 10 \\
\hline Constanta & 4.3 & 4.5 & 4.4 & 4 & 3.6 \\
\hline Galati & 7.9 & 8.9 & 9.2 & 9.5 & 9 \\
\hline Tulcea & 5.8 & 5.9 & 5.9 & 5.5 & 5.5 \\
\hline Vrancea & 5.5 & 5.5 & 5.9 & 6 & 5.5 \\
\hline $\begin{array}{l}\text { South-East } \\
\text { Region }\end{array}$ & 6.1 & 6.4 & 6.7 & 6.9 & 6.6 \\
\hline
\end{tabular}

The Galati area represents $13.36 \%$ of the country's SMEs. More than $50 \%$ of start-ups can be classified as micro-enterprises without employees. Over $95 \%$ of newly created SMEs have a single activity. $55 \%$ of employees working in SMEs are full-time workers and most SME owners have the status of employees of their own company.

The number of companies in the Galati area has experienced positive momentum: more than $10 \%$ growth between 2015 and the years of the economic crisis, 2009-2011 (see Table 5). The fields of construction, manufacturing industry, transport and storage are the most dynamic (see Table 6). In terms of size, the creation of VSEs was the most dynamic: above 15\% for the period 2011-2015 (see Table 7). 
Table 5. South-East Region: the dynamics of business creation by department

\begin{tabular}{|c|c|c|c|c|c|}
\hline Department & $\mathbf{2 0 1 1}$ & $\mathbf{2 0 1 2}$ & $\mathbf{2 0 1 3}$ & $\mathbf{2 0 1 4}$ & $\mathbf{2 0 1 5}$ \\
\hline Braila & 6,056 & 6,248 & 6,377 & 6,470 & 6,464 \\
\hline Buzau & 8,397 & 8,751 & 8,890 & 9,169 & 9,221 \\
\hline Constanta & 19,950 & 20,536 & 20,904 & 21,442 & 21,311 \\
\hline Galati & 10,435 & 11,039 & 11,321 & 11,649 & 11,834 \\
\hline Tulcea & 4,219 & 4,492 & 4,506 & 4,646 & 4,636 \\
\hline Vrancea & 5,915 & 5,931 & 6,103 & 6,284 & 6,379 \\
\hline
\end{tabular}

Source: National Institute of Statistics 2017

Table 6. Galati: the dynamics of the fields of activity in business creation

\begin{tabular}{|l|c|c|c|c|c|}
\hline Field of activity & $\mathbf{2 0 1 1}$ & $\mathbf{2 0 1 2}$ & $\mathbf{2 0 1 3}$ & $\mathbf{2 0 1 4}$ & $\mathbf{2 0 1 5}$ \\
\hline Agriculture, forestry and fishing & 382 & 409 & 406 & 425 & 467 \\
\hline Extractive industry & 12 & 13 & 16 & 19 & 16 \\
\hline Manufacturing industry & 919 & 942 & 966 & 981 & 960 \\
\hline $\begin{array}{l}\text { Production, distribution of } \\
\text { electricity and gas }\end{array}$ & 7 & 10 & 13 & 10 & 11 \\
\hline $\begin{array}{l}\text { Water distribution; sanitation, } \\
\text { waste management, } \\
\text { decontamination }\end{array}$ & 97 & 106 & 113 & 117 & 110 \\
\hline Constructions & 907 & 943 & 978 & 1056 & 1104 \\
\hline Trade & 4,966 & 5,189 & 5,228 & 5,246 & 5,205 \\
\hline Transport and storage & 586 & 647 & 685 & 758 & 800 \\
\hline Hotels and restaurants & 487 & 537 & 547 & 578 & 581 \\
\hline Information and communication & 223 & 238 & 246 & 251 & 263 \\
\hline $\begin{array}{l}\text { Financial intermediation and } \\
\text { insurance }\end{array}$ & 173 & 185 & 206 & 184 & 195 \\
\hline Real estate transactions & 212 & 236 & 244 & 242 & 238 \\
\hline Scientific and technical activities & 682 & 712 & 732 & 777 & 797 \\
\hline Administrations & 315 & 358 & 375 & 387 & 383 \\
\hline Education & 51 & 59 & 57 & 66 & 83 \\
\hline Health and social assistance & 125 & 129 & 139 & 151 & 174 \\
\hline $\begin{array}{l}\text { Cultural and recreational } \\
\text { activities }\end{array}$ & 83 & 89 & 112 & 127 & 151 \\
\hline Other service activities & 208 & 237 & 258 & 274 & 296 \\
\hline Total number of companies & $\mathbf{1 0 , 4 3 5}$ & $\mathbf{1 1 , 0 3 9}$ & $\mathbf{1 1 , 3 2 1}$ & $\mathbf{1 1 , 6 4 9}$ & $\mathbf{1 1 , 8 3 4}$ \\
\hline
\end{tabular}

Table 7. Galati: the dynamics of business creation according to the size criterion

\begin{tabular}{|c|c|c|c|c|c|}
\hline Size of the company & $\mathbf{2 0 1 1}$ & $\mathbf{2 0 1 2}$ & $\mathbf{2 0 1 3}$ & $\mathbf{2 0 1 4}$ & $\mathbf{2 0 1 5}$ \\
\hline $0-9$ & 9,101 & 9,661 & 9,987 & 10,337 & 10,477 \\
\hline $10-49$ & 1,096 & 1,143 & 1,111 & 1,086 & 1,111 \\
\hline $50-249$ & 205 & 202 & 188 & 186 & 207 \\
\hline$>250$ & 33 & 33 & 35 & 40 & 39 \\
\hline
\end{tabular}

\section{Institutions serving entrepreneurship development}

To improve the entrepreneurial climate of the area, various structures and institutions have been created to support the business environment improvement effort. Among these structures founded in Galati, we can mention:

> Romanian River Transport: a cluster that brings together universities ("Dunarea de Jos" University of Galati, "Danubius" University of Galati, "Mircea cel Batran" Naval Academy of Constanta), research institutes (SC IPA SA Bucharest, subsidiary of Galati, the Romanian Center for Staff Training (CERONAV Romanian Maritime Training Centre)) and public authorities (Galati City Hall); it is a question of creating a unitary framework for cooperation among its members, to achieve missions / objectives of common interest concerning the intermodal ecological transport of Romanian internal goods; there are also catalysts for this cluster structure: the Union of Romanian Inland Ports (UPIR) and the Galati Industrial Park.

$>$ Green Solutions Lower Danube: a cluster that brings together universities ("Dunarea de Jos" University of Galati and "Danubius" University of Galati), research institutes (SC IPA SA Bucharest, subsidiary of 
Galati), the Galati Industrial Park and Galati City Hall, in order to keep the entire geographical area of the Lower Danube in a leading position in the renewable energy and energy efficiency sectors.

> IT\&C Cluster Dunarea de Jos, composed of 37 members, both public institutions and companies with IT\&C activities, whose objectives are to exploit the potential of information and communication technologies and their application in the public sector (administration, education, health) and in the private sector (companies, citizens); this association wants to create the premises to increase the competitiveness of companies in the field of ICT, improve the regional competitiveness of ICT education and support entrepreneurship and SMEs in the ICT field in the region.

$>$ Galati Industrial Park: located on the Danube, in the South-East of the city of Galati, with a total area of 21.8 hectares, it has the main objective of supporting local economy and regional development, through research, industry and services, by the enhancement of natural / human resources in the region; this park offers advantages provided by its strategic location:

- immediate vicinity of the Galati Free Zone, on the border with Ukraine and the Republic of Moldova, with access to the Danube, $80 \mathrm{~km}$ from the Black Sea,

- access to the main river transport (Rhine - Main - Danube Canal), to mixed Russian European transport (including highways),

- access to the docks so that participating companies can benefit from port services: loading / unloading various merchandise; storage on concrete platforms and / or in warehouses.

The main activities of the Galati Industrial Park are related to help and support services for entrepreneurs and investors: One-Stop-Shop for the creation of companies, legal advice, tax advice; assistance and advice for non-repayable and / or repayable funding for SMEs; work and cooperation space for mini-entrepreneurs, innovators, researchers; promotion of the co-working system; training through the development of open training programs and obtaining funding for these programs; development of an international cooperation network so that Galati is positioned as a competitive destination connected to the commercial trends of Europe.

> Galati Science and Technology Park: it aims to contribute to the development of the high-tech industrial sector, facilitating the transfer of technology and creating a viable alternative to the labour market in the South-East region; it offers 64 offices of $12,22,42$ or $70 \mathrm{~m}^{2}$, a conference room with a capacity of 70 seats, a multimedia room, a training room, a server room and a space for consultation and research; in 2018 , there were 40 companies operating in the park, with a staff of about 300 people, but the training process of the work teams continues to reach 500 people; the specialized services offered by the park are related to business support for innovation and technology transfer; services of research and development, information, audit, technological watch and prognosis; assistance and consulting services for the development of experimental models and prototypes; assistance and consulting for the exploitation of intellectual property rights; services of access to specialized databases.

$>$ Tehnopol Association of Galati: a community interest organization founded by the Local Council, the General Council, the Chamber of Commerce and Industry, the Software Producers Association and "Dunarea de Jos" University of Galati; this association operates as a tool for local economic development and regional promotion; it runs a business incubator that is organized as an entity without legal personality; the incubator's headquarters is in the IT park building of Galati and its purpose is to facilitate the launch and development of innovative companies based on the information and communication technology; the specialized services are high value-added assistance and consulting services in the form of individual services or services aimed at creating business and innovation relations such as national or international cooperation relations, transfers of technology or know-how, research and development applications, industrial innovation.

$>$ Employers' Federation of SMEs in the South-East Region: an organization created to represent, support, defend and promote the interests of its members before public authorities, trade unions and other legal and natural persons in relation to their object and purpose of activity, both at national and international level.

All these institutions or associations that are involved in the process of improving and stimulating the business environment act as vectors of influence for the dynamics of companies in the Galati area, always with the aim of linking the interests of public and private actors.

\section{Innovative projects carried out by various actors in the Galati area}

After joining the European Union in 2007, Romania has begun a long process of adapting its institutions and public policies to European standards. European funding has determined the creation of development regions to manage European programs / investments, the main purpose of this approach being to improve regional disparities. To develop the entrepreneurial domain, at central and regional level, it aimed at ensuring better communication between ministries, in order to evaluate the legislative plans and projects 
that can influence the development of SMEs, to promote sectors that generate economic growth, business networks, industrial districts and find public funding to support business centers.

Government support initially provided for a partnership between the Ministry of Labour and Social Protection of Romania and the UNDP (United Nations Development Program), which offered a support program for women entrepreneurs (Women Entrepreneurship Development) through coaching in the form of a project analysis and numerous fairs on entrepreneurship, for the purpose of promoting and encouraging business creation. A portal for participatory democracy has also been created, which provides for the identification of national professional associations by sector of activity, such as, for example:

- ANUC (National Alliance of Creators Union), whose objective is to provide information and advice for the development of artistic creation projects and the promotion of their image;

- ALB Romania (Leasing and Non-banking Association), a non-bank financial institution that provides finance leases for SMEs.

Supporting organizations and schemes proposed through European support have provided for the use of the European Social Fund (support fund set up under the European Structural and Cohesion Funds) to help SMEs, through infrastructure development, increased economic competitiveness and strengthening of the administrative capacity; the creation of an online platform for registering formalities and European companies EUGO (EUrope GO) - administrative portals (counters) providing aid and information on the applicable legislation in the sector of activity concerned; the Erasmus program, which allows all European project promoters wishing to set up their business abroad (in Europe) to benefit from financial aid from the European Union - the aid is cumulative in a maximum period of 6 months; a site of business creation services in more than 30 countries (Euro Start Entreprises). Thanks to all these instruments, Romanian entrepreneurs can benefit from funding for their development projects.

Not only at central level, but also at regional and local level, customized and specific support for each sector of activity has been set up in the field of entrepreneurship. In the Galati area, local actors (public authorities, universities, associations, etc.) have developed projects that have made it possible to benefit from the potential gains for the local business community and reduce the widening of regional disparities within Romania.

Among the specific approaches that have supported the development of entrepreneurship in the Galati area, some recent or ongoing programs can be mentioned:

> 2010-2013: "Dunarea de Jos" University of Galati carried the program entitled Training and managerial and entrepreneurial assistance for small and future entrepreneurs, managers and employees of SMEs in the North-East, North-West, Centre and South-East - budget of € 4.8 million (European funding)

The project was developed in partnership with two major multinationals, whose expertise in the field of entrepreneurship has been a strong point: Ernst \& Young and S\&T Romania. The objectives were to promote the entrepreneurial culture and develop managerial skills in small entrepreneurs, selfemployed, managers and employees of SMEs, in the North-East, North-West, Center and South-East Regions of Romania; to create a learning and cooperation network for the transfer of good practices in the field of entrepreneurship and management by creating a web portal and an eLearning application.

This involved 2,880 entrepreneurs and potential entrepreneurs who benefited from 6,500 hours of training and development and more than 150 companies active on the Romanian market who received free advice from Ernst \& Young and S\&T Romania, who provided professional advice to reorganize the company in order to increase the competitiveness of products and services or assistance in the implementation of IT tools for the management of SMEs.

> 2014-2015: "Dunarea de Jos" University of Galati proposed the program The transition from school to working life through the practice and creation of simulated companies -budget of $€ 4$ million (European funding)

This project was in partnership with the National Council of Romanian SMEs and its objectives were to facilitate the transition from school to work for 700 students, through a series of advice, career guidance and innovative actions, in order to develop the entrepreneurial and professional skills necessary for their entry into the labour market. The goal was to develop entrepreneurship and the spirit of innovation with a minimum of 250 students by organizing and implementing simulated business activities.

At the end of the project, the results concerned 811 university students who benefited from individual and group counselling sessions, 274 students who participated in trainings in the 3 simulated companies created and 81 students who benefited from internships in real companies.

$>$ 2017: "Dunarea de Jos" University of Galati created the Student Entrepreneurship Society (SAS-UGAL), a mechanism to support, develop and encourage entrepreneurship for both students and graduates, to increase the competitiveness of the university. This mechanism encourages and supports students to consider entrepreneurship as a career opportunity and helps them to contribute to the emergence of an entrepreneurial economy. In addition, it promotes "Dunarea de Jos" University of Galati as an important local mediator between students and the economic environment and supports strengthening the image of the university as an institution of higher education with entrepreneurial commitment. 
A first project carried out by SAS-UGAL in 2017, called Modern and effective entrepreneurship for students and graduates - budget of $€ 150,000$ (funding from the Romanian Ministry of Education), enabled the development of entrepreneurial skills and aptitudes in students and graduates of "Dunarea de Jos" University of Galati through an entrepreneurship training course and a business ideas competition. The development of the three existing simulated companies allowed a practical internship for 80 students. Moreover, as part of the project, a fair of business plans and an entrepreneurial innovation workshop were organized.

A second project conducted by SAS-UGAL in 2018, called Development, adaptation and transformation in student entrepreneurship (DATAS) - budget of $€ 100,000$ (funding from the Romanian Ministry of Education), aims to create a pilot structure specific to the entrepreneurial activities of students at the faculty level (4 entrepreneurial cells for students), to realize a guide for the student entrepreneur and develop opportunities for collaboration with the industrial environment (agreements on entrepreneurial collaboration with companies, universities, public authorities).

> 2018-2021: "Dunarea de Jos" University of Galati proposes the program entitled Innovative Entrepreneurship in the South-East Region - budget of € 4 million (European funding)

The objectives guide the approach towards boosting the economic environment through entrepreneurship training, non-repayable funding of business ideas, assistance and advice to newly created companies.

At the end of the project, the results will concern the selection and financing of the 72 start-ups (up to $€ 40,000$ for each start-up), the organization of practical and advanced training in digital skills for business management for young entrepreneurs, counselling and personalized services mentoring for each start-up.

$>$ 2017-2019: "Dunarea de Jos" University of Galati, in partnership with 7 European universities and associations, has a project called Open innovation to raise entrepreneurial skills and the public-private partnership in the Danube region (DA-SPACE), in the program Interreg Danube Transnational Programme.

The main idea of this program is to pilot innovative tools and frameworks to stimulate open innovation, while fostering cooperation between innovators from different fields of application and technology. The results of the pilot project will lead to the development of a strategy aiming to stimulate innovation and entrepreneurship in the Danube region.

Specific objectives aim to strengthen entrepreneurial skills and reduce the brain drain, to develop a common framework and a tool for open innovation, to support mutual learning and cooperation in order to increase the skills of employees and employers to better adapt to technological changes and market needs and in the end to extend the cooperation initiative throughout the Danube region.

The project will pilot 7 open innovation laboratories whose researchers (public authorities, universities, companies, young talents) will define a challenge that will be tackled by the solvers (young talents) at the transnational level. Thanks to the co-creation methods, young talents will develop new solutions and business ideas within the laboratory and will also benefit from entrepreneurship training. The exchange between these actors in the DA-SPACE laboratories will allow both parties to benefit:

- young talents will work on real business and can test their ideas in a safe environment, acquiring entrepreneurial skills;

- applicants (SMEs, public authorities, etc.) will test methods of co-creation and open innovation and benefit from the exchange with young innovators. In addition, their employees, involved as mentors in the laboratory, will enhance their professional skills by meeting market requirements and developing skills for future work needs.

The expected results will be linked to the achievement of a transnational strategy to stimulate innovation and entrepreneurship in the Danube region, which will be reflected in the regional action plan. The DA-SPACE laboratories will promote interdisciplinary and transnational cooperation between the various stakeholders capable of generating new solutions and developing the entrepreneurial skills of all the actors involved. All knowledge acquired in the DA-SPACE project will be transferred to four other regions of the Danube through transferability workshops.

> 2015-2020: The project Enterprise Europe Network Eastern Romanian Business Support Network (ERBSN). Enterprise Europe Network is the largest European network dedicated to innovation and internationalization of SMEs, its main objective being to enable SMEs to develop and create new jobs, by encouraging them to become more sustainable and internationally competitive through innovative projects.

The support network for Romanian companies in the East - ERBSN 2015-2020 - was developed by a consortium of five partners, of which three partners oriented towards business and two towards innovation / R\&D, to which was added in 2014 another partner specialized in innovation. ERBSN helps companies identify commercial, technology and / or R\&D partners, advises companies on the European legislation, intellectual property norms and helps them structure their innovation management. This project will also provide feedback to the European institutions on the concerns of regional entrepreneurs and will enable them to participate in the European decision-making process. Each network partner hosts an Enterprise Europe Center offering services in the eastern part of Romania; three of the six partners hosted two Euro Info Centers 
and an Innovation Relay Center and all partners have experience of cooperation and networking or partnership, as well as specialized business and innovation services or implementation of projects funded by various European programs.

- 2015: The project SMART Development Center Association - START UP SMART HUB GALATI - budget of € 2 million (European funding); the partners involved were the Patronage of Romanian Young Entrepreneurs and the Development Consulting Group. Their general objective was to develop entrepreneurial skills and support entrepreneurial initiatives in order to stimulate the self-employment of people over 18 who wanted to start an independent business in the South-East and South-Muntenia Development Regions. The target group was made up of 400 people over the age of 18 from the southeastern and southern regions of Muntenia, people who wanted to work independently

- Finally, we must mention the concept of smart specialization at the territorial level. This concept is based on a process of "entrepreneurial discovery" and aims to identify the areas in which a region excels or has the potential to excel in the future. For the future of Galati, different actors in the area have identified the domains that may create a potential for smart specialization in the South-East Region of Romania. The domains were analyzed in focus groups conducted at the regional level with relevant actors belonging to the quadruple spiral: the public sector, the private sector, NGOs and universities. According to the analysis of economic and social indicators, the domains of smart specialization proposed are the following: engineering (shipbuilding and repair); clothing industry; agribusiness and fishing Biotechnology; ICT, high technology, nanotechnologies and advanced materials.

It is on this basis that the Galati Science and Technology Park is in the process of proposing two new projects:

- A project that aims to develop the Technology Transfer Center of the Galati Science and Technology Park, whose objectives are to promote business investment in innovation and research; to develop links and synergies between companies, research and development centers and education; the technology transfer; the strengthening of the IT\&C cluster of the Danube Delta. Target groups will be private entrepreneurs, academics and researchers and the total cost of the project goes up to $€ 5$ million.

- Another project that will lead to the development of the business incubator in the Science and Technology Park of Galati. It will promote entrepreneurship by facilitating the economic exploitation of new ideas and the networking of actors in the business community: private entrepreneurs, local government and the local population. The estimated cost goes up to $€ 1$ million.

\section{Conclusions}

However, the steps already taken by the different local actors in the Galati region, which have just been presented, seem insufficient, despite the existence of a stable macroeconomic and financial framework that is a precondition for creating an environment favourable to the assertion of the competitive potential of companies. The implementation of a coherent territorial approach in the Galati area must respond to the challenges arising from the need to better exploit the existing economic potential.

The first problematic issue is that the investments supported by the Structural and Cohesion Funds have specific applications, related to certain cities, companies or people. They do not concern the integrated development of specific areas. The main cause is the weak development of forms of public-public, publicprivate or private-private cooperation, despite the efforts made so far, described previously. Other obstacles are related to the management of major projects, regarding institutional and operational differences and the absence of an integrated vision of territorial development.

The second question concerns the current level of decentralization, which seems to be insufficient, since the principle of subsidiarity is mobilized only formally in the design and implementation of territorial policies. It can be said that the cleavage between the top-down approach, initiated at the national level and the bottom-up, locally initiated approach, is mainly due to the fact that local and regional structures have more bureaucratic roles than the competitive mobilization functions of the areas of development.

Thirdly, the role of education in the field of entrepreneurial education, which is not sufficiently developed, needs to be emphasized (either at the secondary or tertiary, university level). Entrepreneurship education has progressed in recent years, both in the national system of pre-university education and in higher education, especially in the process of continuing education through the educational programs of the centers of excellence and in the multitude of training projects available in the Sectoral Operational Program for Human Resources Development. Nevertheless, joint efforts are still needed to create a unitary system of entrepreneurial education, even though pre-university education has taken a decisive step in recognizing it as a cross-cutting objective and in introducing appropriate modules for each level of study. Entrepreneurship training is offered at the university level and successful international models were implemented, such as the exercise companies of the National Center for the Development of Vocational and Technical Education, of the Junior Achievement Romania Association or programmes of the Post-Privatization Foundation that organizes entrepreneurship training courses through a new, rather non-formal, approach like "School for Startups Romania" and "Business Mentoring Programme". 
In conclusion, the main challenges that innovation in entrepreneurship must address are related to the regulations of the business environment, the trust among market actors (companies, institutions, authorities), the resilience of the business environment, but also and especially to human resources and education in order to stimulate creativity, entrepreneurial culture and the innovation community.

\section{References}

1. Nicolescu, O., Popa, I., Ştefan, S., Starea de sănătate a managementului din România în 2015, Editura Pro Universitaria, Bucuresti, 2016

2. Carta alba a IMM-urilor din romania 2017, ediţia a xv-a, editată de Consiliul Naţional al Intreprinderilor Private Mici și Mijlocii din România (CNIPMMR) în parteneriat cu Ministerul pentru Mediul de Afaceri, Comerț și Antreprenoriat, Editura Pro Universitaria, Bucuresti, 2016

3. Cartea verde privind coeziunea teritorială și dezbaterile privind viitoarea reformă a politicii de coeziune, Comisia Europeană, 2009, http://ec.europa.eu/regional policy/archive/consultation/terco/paper terco ro.pdf

4. http://www.insse.ro/cms

5. http://www.think-business.ro/school-for-startups-romania-devine-partener-educational-al-start-me-up/

6. www.interreg-danube.eu/approved-projects

7. http://www.enterprise-europe-erbsn.ro/despre-erbsn/

8. http://www.adrse.ro/Planificare/PDR 2014-2020.aspx

9. http://www.economie.gov.ro/strategia-nationala-pentru-competitivitate-2014-20207

10. http://ec.europa.eu/regional policy/ro/information/publications/communications/2010/regional-policy-contributingto-smart-growth-in-europe-2020

11. www.prbaracademy.ro/file/Ghid\%20Program\%20Mentorat 16.07.2018.doc 